\section{Illusions of pedigree}

\section{J.D. Mollon}

Seeing: Illusion, Brain and Mind. By J.P. Frisby. Pp.160. (Oxford University Press: Oxford, 1979.) £6.95.

THOSE who teach experimental psychology will instantly recognize the pedigree of this handsome colt: it is sired by Richard Gregory out of Lindsay and Norman. It lacks the turn of speed of its parents but proves an excellent stayer on soft ground, is usually reliable over hurdles and should bring rewards to its backers.

Professor Frisby is to be congratulated on an engaging and remarkably lucid introduction to the problems of visual perception. His declared purpose is to combine the psychological, physiological and computational approaches to perception. He has a good judgement of the important issues. Topics covered in detail include feature detection, figureground differentiation, the anatomy and physiology of the visual cortex, object recognition, the computation of lightness, and binocular stereopsis. The concept of spatial frequency and the contrast sensitivity function are deftly introduced for the novice reader. The book is sumptuously and skilfully illustrated and the figures allow readers to experience for themselves many illusions and perceptual after-effects; indeed the author recounts in his preface how he originally set out to produce a collection of illusions for the general reader but, like a novelist taken over by his characters, was soon led to provide the intellectual background. Two-colour anaglyphs, many of them original, demonstrate phenomena of binocular vision. The major omission is a discussion of colour vision; this is odd, even inexcusable, given the lavish facilities available for colour illustration.

The exposition is one of almost unfaltering clarity and this is perhaps the most impressive quality of the book. If Frisby has any fault it is that of spelling points out too much - a virtue in a lecturer but a vice in an author; thus he devotes no less than ten, similar, figures to introducing the concept of a corner-detector.

In elaborating the computational approach to visual perception, Frisby acknowledges an explicit debt to D. Marr "whose writings are for me the work of genius". He discusses in detail, for example, Marr's theory of how the retina computes lightness, that is, discovers the reflectances of surfaces that are unevenly illuminated: bipolar cells detect edges by a centre-surround differencing operation; a threshold is applied to the resulting signal; and then (the "deconvolution" stage) lateral facilitation within one class of ganglion cells causes all cells corresponding to points within a closed boundary to take on the lightness-signal indicated by the signal at the edge. Now, Marr's histological reification of this algorithm is, as Frisby says, "controversial" (to say the least), but there is a more general difficulty. The whole of Chapter 1 was devoted to disabusing the novice reader of a belief in the 'inner screen' theory of perception (the view sometimes called the Gestaltist fallacy); if our novice reader has taken that chapter to heart, then, when he reads Frisby's account of the computation of lightness, he will want to know why the visual system goes to such trouble to produce a picture of the scene in which lightnesses are redundantly represented in the interiors of homogeneous areas, why, that is, the deconvolution is necessary. And he won't be told.

Frisby leaves to a late stage in the book the details of retinal anatomy and physiology. Perhaps it is in this area that he is least sure of himself, for it is here alone that errors occur in any density: in the course of two pages, the inner and outer synaptic layers are confounded, the pigment epithelium and choroid are labelled "sclera", rods are said to be 500 times more sensitive than cones because they contain rhodopsin, the fovea is said to contain only cones, an error of $10^{3}$ is made in equating retinal extent to visual angle, and the amphibian mudpuppy (in a remark apparently lifted almost verbatim from Blakemore) is described as a fish. Undergraduates should be directed elsewhere for their retinal physiology.

The contributions of the editor, Henry Hardy, and the art director, David Warner, are so manifest in this book that their work deserves explicit congratulation. Seeing will be equally in place on the coffee table and on the first-year reading list. I strongly recommend it.

J.D. Mollon is a Lecturer in Experimental Psychology at the University of Cambridge, USY.

\section{Flawed search}

\section{Sara Champion}

\section{In Search of Ancient Astronomies. Edited by E.C. Krupp. Pp.277. (Chatto \& Windus: London, 1980.) $£ 8.95$.}

THIs book arose from a series of lectures given by the contributors in California in 1975 , and is, according to its editor, "the first attempt to present systematically to the general reader the main results of archaeo-astronomy to date". It consists of seven chapters, four by the editor and one each by Professor Thom and his son, Dr John Eddy and Dr Anthony Aveni. It is clearly stated in Krupp's introduction that the "pseudoscientific misconceptions" of Erich von Daniken, Velikovsky and the like are to be "dispelled by the reliable, scientific findings of archaeo-astronomy"; it is unfortunate, therefore, that the majority of the chapters show some misuse or misunderstanding of archaeological data and imprecision in the demonstration of astronomical alignments.

The first chapter by Krupp himself is presented as a non-mathematical introduction to practical astronomy. This is necessary for the understanding of subsequent chapters, and is in general comprehensible, though some of the information could have been transmitted with fewer words and greater clarity.

For many readers the work of the Thoms will be the most familiar, and their chapter on stone circles and menhirs follows. Thom's eminence in the field is largely based on the accuracy of his measurements and the precision of his analysis. Recent papers and reviews have, however, cast doubt on some of his figures, with serious results for his megalithic yard and megalithic calendar (Moir et al. Antiquity LIV, 37-43, 1980). Misidentification of archaeological monuments has resulted in Thom's describing hut circles and enclosures as stone circles of megalithic type, and some of the lines of foresight suggested for certain sites are shown in the field to be below horizon level, difficult to see without binoculars or blocked by natural features not obvious from maps. Some controversial sites appear in this chapter: the Crucuno Rectangle, for example, described by Thom as "lunar standstill alignments", is claimed by Daniel in Antiquity XLIX, 81, 1975, to be an AD eighteenth century folly. For the archaeologist prepared to be convinced, some of Thom's claims appear thin and several statements contentious. To be told that, at Rough Tor in Cornwall, many of the upright stones have fallen and the remaining ones do not adhere closely to the flattened circle design, perhaps because of solifluxion, begs the question - what flattened circle design is there left to be measured. Rules about the use of megalithic yards are stated, only for exceptions to be made immediately: "the sides of these triangles all had to be integers in megalithic yards", followed by "the builders discarded the rule that all radii must be integers".

The third chapter, by Krupp, deals with the work by archaeo-astronomers and others on the site of Stonehenge, several of whose papers have appeared in Nature. In general the treatment is descriptive rather than critical, which may be misleading for the general reader. Analysis of Hoyle's claim that Stonehenge was an eclipse predictor has been published by Moir (Antiquity LIII, 124-128, 1979); he points 
out the problems of refraction, visibility, and variability in moonrise and moonset positions due to declination and perturbation which would affect the use of the site in this way. The same criticisms can be applied to Thom's work where it involves lunar observations. Again, the misuse of archaeology undermines attempts to prove alignments: Krupp's use of Figsbury Ring, at least 1,000 years later in date than Stonehenge, as a foresight for the southern major standstill moonrise, is inexcusable.

Eddy's chapter on North America is the only one in the book where a sensible caution appears. His balanced view of others' work is exemplified by his regard for the archaeology as equally important as the astronomy in the analysis of the Chaco Canyon structures. His own work on the Indian medicine wheels is a model of careful and logical procedure. The same cannot be said of Aveni's chapter on
Mesoamerica, where sites a millennium and several hundred miles apart are grouped on the basis of their similar orientation. The use in this chapter of words like "nearly", "close to" and "approximate" when describing alignments destroys their credibility. The claimed alignment of Teotihuacán on the setting of the Pleiades turns out to be "within 1 degree" of this event, a difference representing a sizeable slice of the horizon. Misunderstanding of archaeological data in this chapter results in Aveni using Flannery and Marcus' application of central place theory to Mayan settlements as evidence of geometrical and possibly astronomical location of these sites.

Krupp's chapter on Egyptian astronomy, mainly descriptive of previous work, is followed by his attempt to debunk von Däniken and the rest. His handling of the leyline controversy and the Glaston- bury Zodiac lacks conviction, since he frequently ignores the most obvious line of attack; for example, he reproduces without comment the notorious leyline that runs from Stonehenge (third millenium BC) through Old Sarum (sixth century BC) to Salisbury Cathedral (AD twelfth century).

With the exception of Eddy's chapter, the book fails on its own terms, for it presents to the reader a picture based, in many cases, on misunderstood archaeological evidence and selective or imprecise numerical and astronomical data. The non-expert may unfortunately be persuaded by the jaunty air and punning subheadings (e.g. "A Serious Mystery" for a section on Sirius) into believing it all.

Sara Champion is Hartley Fellow of the University of Southampton, UK, in the Department of Archaeology.

\section{FRS extraordinary}

\section{J. Z. Fullmer}

Benjamin Thompson, Count Rumford. By Sanborn C. Brown. Pp.576. (MIT Press: Cambridge, Massachusetts, and London, UK, 1979.) $\$ 19.95, £ 12.40$.

BENJAMIN Thompson, born in March 1753 in Woburn, Massachusetts, died Benjamin Thompson, Count Rumford, in August 1814, in Auteuil, France. By almost any criteria his biography should make a rattling good yarn, for his adventurous life had episodes of intrigue, of mystery and of passion. He promoted large scale social experimentation and technological innovation; he interpreted his scientific experiments in ways that propelled him into controversy with the conservative members of the scientific community. When young and a volunteer member of the American army he functioned as a Royalist spy. In the spring of 1776 , he fled to England, where he promptly ingratiated himself with influential British government officials. In 1783 he went to the Continent, becoming an agent for the British in Munich (or, perhaps, a double agent - the record is cloudy). Subsequently he shuttled back and forth between England, Ireland and Europe with no apparent regularity or design, his movements dictated by opportunity. He acknowledged two illegitimate children, one in Munich, the other in Paris, and sired one legitimate child, Sarah, born in Massachusetts. Assured that his abandoned American wife was truly dead, he married Jeanette Lavoisier (née Paulze), Antoine Lavoisier's widow, from whom he was soon divorced after a series of spectacular and public brawls. Moreover, during long periods in England and on the Continent he associated closely with well-placed reputed homosexuals, furthering his own career through these connections.

He managed to be close to centres of power in the government circles to which he propelled himself, and in the international scientific community. In 1780 he was elected Fellow of the Royal Society - he was 27 - after having attracted favourable notice for his very long paper on the nature of heat. For nearly a decade he earned the attention of Karl Theodore, the Elector of Bavaria, to whom Rumford owed his honorary title. The scientifically conservative Napoleon showered attention on him, and in England Sir Joseph Banks, PRS, abetted some of his plans. Rumford published a large number of papers: on the nature of heat and of light; on the best designs for stoves; on ways to feed the poor; on the efficient use of fuels in kitchens and fireplaces; on the boring of cannon; and on a pot for brewing coffee. He laid out the English Gardens in Munich; he devised plans to reduce beggary in Bavaria while feeding and clothing the army; he promoted the erection of a technological museum that offered visitors 'hands-on' experiences; he attempted to educate artisans in the factory ways of the industrial revolution; together with Banks he founded the justly famed Royal Institution of Great Britain.

Yet even this extensive listing of his promotional efforts does not exhaust them. While still alive Rumford proferred sums of money to England and America, endowing the prizes known as the Rumford Medals of the Royal Society and of the

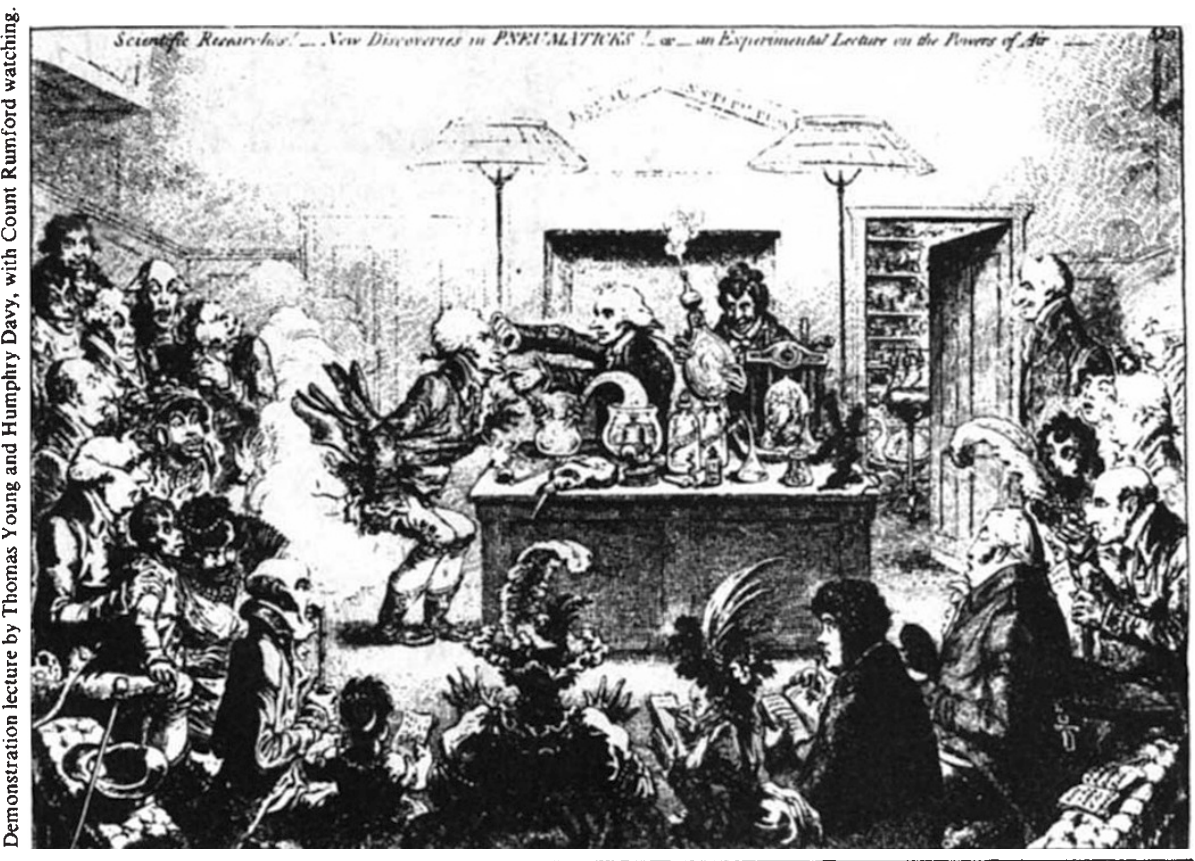

